\title{
What do consumers know about the economy?
}

\section{A test of minimal economic knowledge in Germany}

\author{
Inga Wobker · Peter Kenning • Marco Lehmann-Waffenschmidt • \\ Gerd Gigerenzer
}

Received: 4 September 2013/Accepted: 29 January 2014/Published online: 28 March 2014

(C) Bundesamt für Verbraucherschutz und Lebensmittelsicherheit (BVL) 2014

\begin{abstract}
This research investigates Minimal Economic Knowledge (MEK) of consumers in Germanythat is, basic economic knowledge needed for understanding and successfully participating in the economy. First we develop a scale for measuring MEK in four economic domains: finance, labour economics, consumption, and public economics, testing for three kinds of knowledge within each domain, namely facts, concepts, and causal relationships. Second, we conduct an empirical study to test MEK level and influence of demographic drivers in a representative sample of German adult consumers $(N=1,314$ ), with a mean result of only 59.4 points (of 100), indicating a considerable lack of even minimal economic knowledge. And third, using a subsample, we study factors that result in differences in the level of MEK showing among others that the choice of "sensationalist" versus "serious" news sources, both on television and in newspapers, is associated with a loss of about 10 MEK points, while, surprisingly,
\end{abstract}

Electronic supplementary material The online version of this article (doi:10.1007/s00003-014-0869-9) contains supplementary material, which is available to authorized users.

I. Wobker (凶) · P. Kenning

Zeppelin University, Am Seemooser Horn 20,

88045 Friedrichshafen, Germany

e-mail: i.wobker@zeppelin-university.net

M. Lehmann-Waffenschmidt

Dresden University of Technology, Helmholtzstraße 6-8, 01062 Dresden, Germany

G. Gigerenzer

Max Planck Institute for Human Development, Center for Adaptive Behavior and Cognition, Lentzeallee 94,

14195 Berlin, Germany participating in an economics course did not enhance minimal economic knowledge. The article closes with a discussion of implications for consumer policy-making.

Keywords Consumer education . Economic literacy · Laypersons ·

Minimal economic knowledge · Drivers

\section{Introduction}

Consumers are part of a society that today is characterized by an economization of all aspects of life. However, acting in the economy is associated with uncertainty, (financial) risks and potential dangers for consumers (Oehler 2011). One way to decrease such associated dangers is knowledge (Werner and Oehler 2009). Consequently, a basic understanding not only of consumer issues but also of economic issues in general is increasingly a key requirement for an educated consumership.

Against this background, the aim of this article is to contribute to the economic literature by testing the level and drivers of minimal economic knowledge (MEK) in Germany. To achieve this, our paper includes conceptual and empirical studies. First, we apply a Delphi method to conceptualize and develop a questionnaire for assessing MEK at the individual level. Second, we empirically test the status quo of the general population's MEK and the influence of demographical drivers and, finally, we test several factors for differences in the level of MEK.

The paper is organized into five sections. Section 2 discusses the current level of research on economic 
knowledge and introduces our hypotheses. In Sect. 3 we present the development of the MEK questionnaire by using the Delphi method. Section 4 describes the empirical studies we ran to test several hypotheses related to the MEK level and presents the results. A major result is that the mean MEK is only 59.4 points (of 100), demonstrating a lack of even minimal economic knowledge. Moreover, we found gender, education, and age as MEK drivers, as hypothesized. Section 5 provides a discussion of the results and conclusion.

\section{Literature review and hypotheses}

Knowledge is traditionally defined as justified true belief' (Nonaka 1994), and it is a 'critical resource that enables individuals [...] to solve problems' (Evanschitzky et al. 2007, p. 272). Accordingly, economic knowledge encompasses all knowledge that enables subjects to solve economic problems (Steiner 2001). The problems that consumers must solve range from everyday purchase decisions to complex financial investment decisions, and the ability of those persons to make good decisions is a result of economic experience and education (van Witteloostuijn 1990). For our focus on MEK, we define the concept as basic knowledge of the economic facts, concepts, and causal relationships needed for understanding and participating in the economy. That said, we assume that MEK is likely to contribute to sound, economic decision-making.

A clear understanding of MEK is conveyed by the relevant literature. Beside others, Walstad and Allgood (1999) demonstrate that the general public has little knowledge of basic economics, and that even college or university graduates who had taken an economics class could not correctly answer many basic economics questions. Knowledge and opinions on current issues in American economic politics were also examined in a representative study by Blinder and Krueger (2004). Their evaluation of nine knowledge questions revealed that on average participants could answer $42.9 \%$ of the questions correctly; however, the standard deviation $(S D=16.7)$ was relatively large. Participants' knowledge was dependent on their socio-economic status and level of political engagement. Among the demographic variables, an especially strong influence was seen for gender, race (white or black), age, and education.

Supplementary Table 1 provides a comprehensive overview of the most citied studies that test economic knowledge and/or that develop a model of economic knowledge. The main finding from our review is that a substantial heterogeneity exists regarding measurements, models, and subjects. Moreover, only a limited number of empirical studies address economic knowledge outside the US (with notable exceptions such as Bucher-Koenen and Lusardi 2011; Enste et al. 2009; Jappelli 2010). However, the specific economic knowledge relevant for the US is not entirely generalizable to other countries, given the differences in (economic) systems of various countries, and other sociological factors-for example, general education level and cultural meaning of the economy. Furthermore, those studies often target much narrower aspects of economic knowledge, such as the sub-area of financial literacy, which is defined as the ability to understand financial tasks and to make informed and effective decisions through an understanding of finances (Chen and Volpe 1998). However, financial literacy is a very specific domain. In everyday life a broad range of economic literacy is needed, such as in the areas of labour economics and consumption decisions.

Additionally, to enhance consumer knowledge, an essential feature of the current consumer policy in many countries is the 'information paradigm': to provide consumers with extensive information e.g., about products and business practises, assuming that this will enhance their decision quality (Kenning and Reisch 2013; Micklitz et al. 2010). This paradigm dates back to John F. Kennedy, who established in the Consumer Bill of Rights-among other rights-, the right of consumers to be informed by businesses in order to make the right and appropriate choices (Kennedy 1962). However, information reception is dependent on one's education and knowledge (Pressley et al. 1989) and supplying information to consumers may not automatically be associated with better choice-making behaviour (Jacoby 1977; Oehler and Reisch 2008). Therefore, this information-based approach was later extended by the United Nations Guidelines for Consumer Protection to include a right to consumer education, which faciliates the possibility for acquiring "knowledge and skills needed to make informed, confident choices about goods and services, while being aware of basic consumer rights and responsibilities and how to act on them" (United Nations 1985).

However, policy makers dealing with issues on consumer education and knowledge need information and knowledge for their policy making, too (Oehler and Kenning 2013). For instance, in order to assess how high the level of knowledge of a consumership is, a test to measure individual levels of 
economic knowledge first needs to be developed. Then the level of this knowledge has to be tested before measures to develop this economic knowledge can be taken. As it is not possible to measure the economic knowledge in its whole width, policy makers could target the level of MEK, thereby taking on a protection perspective of vulnerable consumers (Micklitz et al. 2010). Measuring the MEK in the population is relevant in several aspects with regard to individuals and makers of public policy:

First, the necessity for effective measurement of general economic knowledge develops, in part, from the need to recognize that a deficit exists. Though having a low level of economic knowledge does not prevent consumers from taking action as if they were economically literate (Steiner 2001), the lack of knowledge may, unfortunately, lead them to make unsound economic decisions (Lusardi and Mitchell 2011). It is therefore important to recognize the degree to which the consumership does-or does not-understand these matters, and this can only be accomplished through accurate assessment.

Second, although (consumer) policymakers maintain an ideal of citizens as mature consumers (Federal Republic of Germany 2005; Reisch 2004), biases in laypersons' perceptions of (consumer) policies are often due to inadequate economic knowledge (Enste et al. 2009; Roos 2007). It remains open whether consumers are as mature and educated as commonly assumed. Because public opinion affects government policymaking (Hill and Hinton-Anderson 1995), it is important to increase the economic literacy of the population. Given that when there is better understanding of causal relationships between the policies that improve individual and social welfare, those policies can gain greater public acceptance.

Third, for consumer protection it is important to be aware if consumers have knowledge deficits and may need special guidance or protection in their economic decision-making. Especially consumers with a low level of knowledge about products, offers, and rights are vulnerable (Micklitz et al. 2010) and may make wrongful purchase decisions because they are often confused in the market (Kenning and Wobker 2012). In fact, more and more consumers find it difficult to cope with the (economic) challenges of everyday life (Kenning and Wobker 2013). Such consumers are at risk of being excluded from social and economic life, whether by excessive debt or lack of communication. These vulnerable consumers and their low level of economic knowledge may need special attention from consumer policy makers (Kenning and Wobker 2013). To assess the economic knowledge of this target group, the ability to measure MEK is therefore an important tool. Against this background, we conclude that there is a need for a distinct questionnaire to measure economic knowledge in Germany. In order to fill this gap, the goals of this paper are (1) to develop this specific MEK questionnaire and (2) to investigate and explore what drives MEK. With respect to this goal, we theorize, in the following section, on several hypothesis concerning potential drivers of MEK.

\subsection{Hypotheses development}

Gender. Due to different types of socialization that take place within the family, academics, and the economy, gender is assumed to have an influence on levels of economic knowledge. This gender differential is borne out in previous studies that show women typically scoring slightly lower on economic tests and surveys (Gleason and van Scyoc 1995). A reason for this may be that, socio-historically, men have a more deeply rooted background in business and economics. This historical pattern of heightened interest has resulted in generally better economic knowledge among males (Walstad and Soper 1989). Furthermore, women continue to face economic disadvantages, as in the example of the wage gap that can be observed in many professions (Weck-Hannemann 2000). We therefore test the hypothesis that women have a lower MEK than men $\left(H_{1}\right)$.

Education. A broad spectrum of knowledge acquired through years of learning provides people with an 'adaptive toolbox' (Gigerenzer 2014) for solving problems. People with more (general) education are likely to be more literate, and better able to understand economic issues; hence, they have greater economic knowledge (Caplan 2002; Jappelli 2010). As well, research has confirmed that economic knowledge is related to education (Walstad 1996). We therefore predict that the more education a person has, the higher his or her MEK is $\left(\mathrm{H}_{2}\right)$.

Age. Though mental fitness increases with age, it reaches a peak level, after which it begins to decline. In the typical life span, physical strength and brain tissue increase up to age 40, or even 50 (Kaplan et al. 2000). With respect to (economic) knowledge, this suggests that the older a person is, the more that person knows, having over time accumulated personal experience with, and knowledge about, the economy (Walstad 1997). At a certain age, however, cognitive functions start to decline (Nilsson et al. 2009). With this diminishing of somatic tissue 
(Kirkwood 1990) and mental productivity, it is reasonable to expect that economic knowledge also declines. We therefore hypothesize that there is an inverted U-shaped relationship between age and $\operatorname{MEK}\left(\mathrm{H}_{3}\right)$.

A further goal of our research is to use an explorative approach to identify factors that result in different levels of minimal economic knowledge. As a basis, we develop several investigative hypotheses regarding the effect that a person's origin, life experience, social circumstances, and use of media on one's own MEK level.

Socialization. Experience is necessary for the evolution of knowledge (Nonaka 1994). In societies whose its members have fewer opportunities to collect relevant experiences, less knowledge can be expected. For instance, those persons who lived in the former communist East Germany are less likely to have had opportunity to participate in a free market economy. This created a lack of experience with, and therefore knowledge of, economic principles (Howard 2003). In contrast, a relatively free economic system dominated in the former West Germany, giving those residents a stronger basis for understanding economic issues. The divergent experiences with the economies of East and West Germany have resulted in a continuing structural inequality between the two regions of a unified Germany. Even twenty years after a social market economy was introduced to East Germany, the historical situation of the economy may continue to affect economic knowledge at the individual level (Bucher-Koenen and Lusardi 2011; Jappelli 2010). Therefore, our hypothesis is that citizens who were been socialized in East Germany have a lower MEK than citizens who were socialized in West Germany $\left(\mathrm{H}_{4}\right)$.

Personal motive. Consumers for whom the economy has increased personal relevance (such as having major investments, being unemployed, or being self-employed) should pay greater attention to pertinent economic information and should gather more information about economic issues (Genova and Greenberg 1979; Williamson and Wearing 1996). We therefore expect that people who recently had a personal motive to engage with the economy have a higher MEK score than people who recently did not have a personal motive to engage with the economy $\left(\mathrm{H}_{5}\right)$.

Economics course. An economics course should improve understanding of the economy given that economic concepts are taught (Walstad 1996).
Consumers with a higher level of economic education should therefore have a higher MEK because they have had more exposure to economic issues and should generally be better trained in economics (Gleason and van Scyoc 1995). Therefore, we expect that people who took an economics course have a higher MEK score than people who did not $\left(H_{6}\right)$.

Television consumption. Although television can provide a vast amount of information (Gripsund 1999), people with high television consumption levels typically have a lower level of education (Hancox et al. 2005). We expect that there is also a correlation between high television consumption and economic knowledge, and hypothesize that the more television a person watches, the lower his or her MEK score will be $\left(H_{7}\right)$.

Yellow press and sensationalist television news. That a person makes an effort to be informed about the economy is important, but the level of economic knowledge will also depend on the sources of information. We expect that the type of newspaper and television consumed will affect economic knowledge, and we hypothesize that readers of the yellow press have a lower MEK score than readers of 'serious' newspapers $\left(H_{8}\right)$ and that viewers of sensationalist television news have a lower MEK score than viewers of 'serious' news $\left(H_{9}\right)$.

Socio-political opinion. We assume that a person's level of economic knowledge will affect what he or she thinks about current socio-political topics (Caplan 2002). With increased knowledge, people should be better equipped to understand the principles of the economic issues and policy making, and to form their opinions accordingly. We therefore assume that differences in levels of MEK will be associated with differences in socio-political opinion $\left(\mathrm{H}_{10}\right)$.

\section{Development of the MEK questionnaire}

\subsection{Delphi Method and pretesting}

One aim of this article is to develop a valid scale for assessing the MEK of consumers. The basis for our scale development is the methodology used to develop a scale for Minimal Medical Knowledge (MMK; Bachmann et al. 2007). Accordingly, we draw on the recommendations of economics and business professors who have been asked to suggest a range of economic questions. The objective is to produce a set of questions that represents different levels of economic knowledge, but that would be understandable 
for all consumers, even those with a low or moderate interest in the economy. ${ }^{1}$

In order to capture not just one but many aspects of the economy we conceptualize MEK to cover four domains: finance, labour economics, consumption, and public economics. Within each domain, we distinguished three kinds of knowledge according to our definition: facts, ${ }^{2}$ concepts, ${ }^{3}$ and causal relationships. ${ }^{4}$ On that basis, a first questionnaire with 24 questions ( 4 domains $* 3$ kinds of questions $* 2$ questions per category) was constructed. All questions had five possible answers, only one of which was correct. The correct answers yield one point and the wrong answers yield zero points. All points are totalled and then multiplied by the factor $4.17(=100 /$ 24) to standardize the results. The possible values of the MEK thus range between 0 and 100 .

To validate the first version of the questionnaire, we obtained opinions from a committee of independent experts. Fourteen experts-colleagues drawn from business, economics, and finance-were invited to participate in a committee based on the Delphi method (Linstone and Turoff 1975). Seven of those experts agreed. $^{5}$ In an iterative process, the experts then reviewed the questionnaire in a first round. We collected and compared their annotations and, based on their comments, modified the questionnaire.

To pretest the revised version of the MEK questionnaire, we ran computer-assisted telephone interviews (CATIs) for a sample of 96 participants. First, the MEK distribution was determined, which averaged $M=58.5(S D=14.2$, range $=28-92)$. If sample participants had difficulty understanding the wording of questions, we adjusted the language. Some questions had to be replaced entirely.

In the next step, we resent the revised questionnaire to the committee of experts, with indications of the amendments, as well as the results of the first

\footnotetext{
${ }^{1}$ Certainly, economic experts and persons with a university degree in economics have knowledge far superior to the minimal economic knowledge that we define here, and that we perceive as essentially important. However, it was not the goal of our questionnaire to test expert knowledge, but rather the knowledge of laypersons.

${ }^{2}$ e.g., 'How high is the unemployment rate in Germany right now?'

${ }^{3}$ e.g., 'What is meant by the liquidity of a company?

${ }^{4}$ e.g., 'What effect does a jump in value of the US dollar have on the German economy?'

${ }^{5}$ Expert names and affiliations are provided in the electronic supplementary material.
}

survey. The experts considered this set of questions to be valid for assessing minimal economic knowledge.

We then tested the final questionnaire in a second survey, interviewing 54 participants through CATIs. For this survey the average MEK was $M=67.6$ $(S D=15.0$, range $=36-92)$. This difference of almost 10 points in mean MEK can be explained by the revised set of questions.

\subsection{The MEK questionnaire}

On the basis of the Delphi study and the two pretests, a final version of the questionnaire emerged (Table 2 , available as electronic supplementary material), with 24 knowledge questions covering four domains (finance, labour economics, consumption, and public economics) and three kinds of knowledge (facts, concepts, and causal relationships). We also established additional measures as follows in order to test the hypotheses.

Demographic information integrated into the questionnaire included gender ('0 = female', $' 1=$ male'), ${ }^{6}$ age (in years), highest educational degree $^{7}$ and income (net household income in $€$ ), information behaviour, and self-assessment of economic knowledge. ${ }^{8}$

For socialization we asked consumers over 35 years (the population who grew up with and/or lived in a separated Germany) in which state they attained their highest educational degree. We then classified these states in East and West Germany. For personal

\footnotetext{
${ }^{6}$ Danaher and Crandall (2008) expanded the view proposed by Williams et al. (1992) that women typically score lower on economic tests, showing that girls who were asked to indicate their gender before being tested in mathematics had weaker scores than girls who did not indicate their gender; for females, apparently, designating gender activates negative stereotypes and thereby decreases performance (Schmader et al. 2008). In order to avoid stereotyping, we did not assess gender until the end of the questionnaire.

7 Responses were scaled ' 1 = Haupt- oder Realschulabschluss', comparable to general or intermediate secondary school, ' 2 = Lehre oder Ausbildung', comparable to an apprenticeship or vocational training, ' 3 = Meister', comparable to master craftsman, ' 4 = Abitur', comparable to A-Levels, ' $5=$ Studium', equalling university or college studies, ' $6=$ Promotion' equaling PhDs or professors.

${ }^{8}$ Consumers were asked to rate their economic knowledge prior to the knowledge questions, and then were asked to rate it again after answering the knowledge questions, using a scale from ' $1=$ I belong to the worst $20 \%$ of the population' to ' $5=$ I belong to the best $20 \%$ of the population.' The purpose of asking participants to respond to this question twice was to capture the affective as well as the cognitive aspects of selfassessment, and to avoid common-method bias (Podsakoff et al. 2003).
} 
motive, we asked whether or not they had a reason for engaging with the economy in the prior six months. For those who answered affirmatively, we asked openly about the situation or reason. For economics course we asked if they had ever taken an economics course and if so, what kind of course. We further asked about the number of hours of television consumption per day and the consumption of newspapers and television news. ${ }^{9}$ We evaluated sociopolitical opinions by asking participants whether they were in agreement with the controversial issues of the high-speed railway station project 'Stuttgart 21'; the extension of operating times for German nuclear power plants; and the theses on immigration, and especially on Muslim immigration to Germany, upheld by Thilo Sarrazin, former Executive Board member of the Central Bank of the Federal Republic of Germany. ${ }^{10}$

\section{Empirical surveys}

\subsection{Determination of MEK status quo}

\subsubsection{Data collection and characteristics of the sample}

To measure the MEK status quo for the German population, we conducted an empirical study in Germany between July and August of 2010. The data were collected using CATIs from a national random sample of 1,314 adult consumers. Of the participants, $50.5 \%$ were female. Age ranged from 18 to 84 years, with a mean of $M=46.6$ years $(S D=15.9)$ and a median of 46 years $(N=1,314)$. Different socioeconomic backgrounds were represented in this study, and the average monthly household income (for those persons surveyed who voluntarily reported their income), ranged from $0-10,000 €$, with a mean

\footnotetext{
${ }^{9}$ Respondents were classified as yellow press readers if they read the 'Bild-Zeitung' at least once a week but never the 'Handelsblatt' or the 'Frankfurter Allgemeine Zeitung'. 'Serious' newspaper readers were classified as such if they read the 'Handelsblatt' or the 'Frankfurter Allgemeine Zeitung' at least once a week but never the 'Bild-Zeitung'. Respectively, we classified consumers as sensationalist news viewers if they watched 'RTL aktuell' at least once a week but never 'heute/ heute journal' or 'Tagesschau/Tagesthemen'. 'Serious' news viewers were classified as such if they watched 'heute/heute journal' or 'Tagesschau/Tagesthemen' at least once a week but never 'RTL aktuell'.

${ }^{10}$ Respondents who indicted a neutral opinion where not entered into the analysis.
}

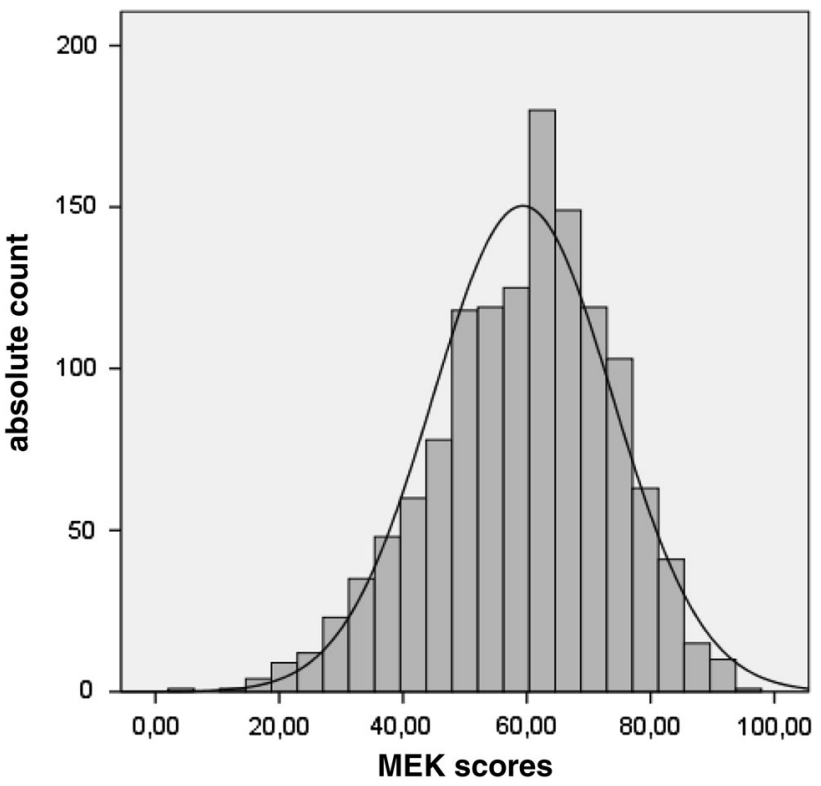

Fig. 1 Distribution of MEK scores in a representative survey of Germans

of $2,253 €(S D=1,523 €)$ and a median of $2,000 €$ $(N=580)$.

Responses indicated that $30.6 \%$ of the participants held a university degree $(N=1,303)$. With regard to geographic location, $16.0 \%$ of the sample inhabited region that formerly comprised the states of East Germany $(N=210), 81.6 \%$ were from the former West German states $(N=1,072)$, and $2.4 \%$ of the sample lived in the city state of Berlin. ${ }^{11}$ Basing our demographic evaluation on the most recent population survey of the Federal Statistical Office of Germany (2010), we found our overall sample to be similar to the broader German population with respect to age, gender, education, income, and geographical socialization. Analyses were performed using the IBM SPSS Statistics 20.0 software package.

\subsubsection{Empirical results}

The overall average MEK was $M=59.4(S D=14.5$, $N=1,314$, range $=4.17-95.8$, see Fig. 1). Differences in the level of MEK were observable between the four domains and the three kinds of knowledge, with the lowest scores in the domain of labour economics, and particularly for the question concerning causal relationships (see Table 1). Public economics/concepts scored the highest rate of accuracy, and labour economics/causal relationships scored the lowest results.

\footnotetext{
${ }^{11}$ Because Berlin was divided between East and West Germany during the German separation, this sub-sample is excluded in the analysis of the two former parts of Germany.
} 
Table 1 Correct answer rate by area and type of question

\begin{tabular}{llllrr}
\hline & Finance (\%) & Labour economics (\%) & Consumption (\%) & Public economics (\%) & $\emptyset$ (\%) \\
\hline Facts & 75.5 & 45.8 & 41.3 & 62.5 & 56.3 \\
Concepts & 72.5 & 44.6 & 81.9 & 82.3 & 70.3 \\
Causal relationships & 58.0 & 29.2 & 46.9 & 35.3 & 62.4 \\
$\varnothing$ & 68.7 & 39.9 & 56.7 & 60.0 \\
\hline
\end{tabular}

Table 2 Sources of information about the economy

\begin{tabular}{lc}
\hline Source & $\%$ \\
\hline General news (print, TV, radio) & 66.9 \\
Specific radio and television programs with an economic & 59.5 \\
$\quad$ focus & 54.2 \\
Specific print media with an economic focus & 35.9 \\
Specific online media with an economic focus & 31.7 \\
Elementary or secondary school & 30.2 \\
Job & 28.9 \\
College and university studies/apprenticeship & 28.9 \\
Discussions with friends or colleagues & 11.1 \\
On-the-job training (e.g., internal continuing education) & 9.8 \\
Training in spare time (e.g., adult education, lectures) & 9.8 \\
\hline
\end{tabular}

Income correlated with MEK $r=0.27^{12}(N=580)$. The mean of the affective self-assessment was 3.2 $(S D=0.9)$ and the mean of the cognitive self-assessment was $3.4(S D=1.0)$, with a resulting average mean of $3.3(S D=0.9)$. Notably, women expected their own knowledge to be lower $(M=2.93$, $S E=0.03, \quad N=656)$ than did men $[M=3.34$, $S E=0.03, N=648]$. Results showed that only $43.9 \%$ of the participants could accurately predict the level of their economic knowledge. $18.2 \%$ of the participants underestimated their economic knowledge, whereas $37.9 \%$ overestimated their economic knowledge, thereby indicating a tendency towards overconfidence (Blavatskyy 2009).

We also asked participants to indicate the sources of their economic information. Table 2 lists the percentage of use for the ten most frequently accessed sources. General news in print, television, and radio were the most popular sources of information, followed by specific radio broadcasts, television programmes, and print media (newspapers or magazines). On average, each participant reported three

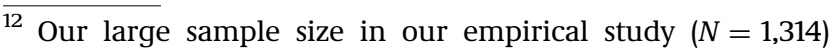
obviously produces small $\mathrm{p}$-values in the regression analysis and the $t$-test comparisons. To make the article simple and readable, unless noted otherwise, all $p$-values are $p<0.001$ (for a discussion on the usage of statistical significance please refer to Krämer and Gigerenzer 2005).
}

sources of information. The correlation between the number of sources a participant used and the MEK value was positive but small $(r=0.13)$.

To test our first three hypotheses, we conducted two kinds of analyses: First, we report differences in MEK levels due to certain hypothesized drivers. To further allow an interpretation of the strength of those drivers, we used a multiple linear regression analysis applying OLS. This second analysis led to the following regression equations:

$$
\begin{aligned}
\text { Regr. } 1: \text { MEK }= & \beta_{0}+\beta_{1} \text { GENDER }+\beta_{2} \text { EDUCATION } \\
& +\beta_{3} \text { AGE }+\epsilon .
\end{aligned}
$$

Regr. 2 : MEK $=\beta_{0}+\beta_{1}$ GENDER $+\beta_{2}$ EDUCATION

$$
+\beta_{3} \mathrm{AGE}+\beta_{4} \mathrm{AGE}^{2}+\epsilon \text {. }
$$

The first model could explain an adjusted $R^{2}$ of $19.1 \%$ of the variance of MEK and for the second regression an adjusted $R^{2}$ of $20.2 \%(F$ change $=18.9)$, thereby indicating that the inclusion of a quadratic term of age improved our model and allowed the modelling of the inverted U-shaped function of age. We did not identify noteworthy violations for the estimated models with respect to multicollinearity (O’Brien 2007) or heteroscedasticity (Cook and Weisberg 1983). For an overview of the regression results, see Table 3.

Hypothesis $\mathrm{H}_{1}$ predicts that there is a gender effect on MEK. Indeed, women yielded an MEK mean of $55.6(S E=0.55, N=664)$, and men a mean of 63.2 $(S E=0.55, N=650)$. The standardized estimates show that male participants have higher MEK than female participants (Regr. 1: $\beta_{1}=0.20$; Regr. 2: $\beta_{1}=0.22$ ), so $H_{1}$ is supported.

Hypothesis $\mathrm{H}_{2}$ predicts that education has a positive effect on MEK. On average, consumers with a college or university degree scored ten points higher $(M=66.3, \quad S E=0.59, \quad N=399)$ than consumers without a degree $(M=56.4, S E=0.48, N=907)$. As Regr. 1: $\beta_{2}=0.34$ and Regr. 2: $\beta_{2}=0.34$ we find support for this hypothesis as well.

Hypothesis $\mathrm{H}_{3}$ proposes an inverted U-shaped quadratic relationship between age and MEK. Age 
Table 3 Regression results

\begin{tabular}{llrl}
\hline & $\begin{array}{l}\text { Standardized } \\
\text { estimates }\end{array}$ & $t$-values & $p$-value \\
\hline Model 1 & & & \\
$\quad$ Gender (female/male) & 0.20 & 7.92 & $<0.001$ \\
Education & 0.34 & 13.51 & $<0.001$ \\
Age & 0.13 & 5.30 & $<0.001$ \\
Constant & & 31.37 & $<0.001$ \\
Model 2 & & & \\
Gender (female/male) & 0.22 & 8.47 & $<0.001$ \\
Education & 0.34 & 13.60 & $<0.001$ \\
Age & 0.15 & 5.89 & $<0.001$ \\
Age squared & -0.11 & -4.34 & $<0.001$ \\
Constant & & 31.88 & $<0.001$ \\
\hline
\end{tabular}

Dependent variable: MEK. Model 1: $R=0.439, R^{2}=0.193$, adjusted $R^{2}=0.191, d f=3,1289, F=102.45, p<0.001$. Model 2: $R=0.452, R^{2}=0.204$, adjusted $R^{2}=0.202, d f=4,1288$, $F=82.62, p<0.001$

followed an inverted U-shaped quadratic function first, with an increase peaking at an age of about 60 years. The average MEK for those in the 'young' age category (below 46 years-as determined by a median split) was 57.9 ( $S E=0.58, N=640)$, while the average in the 'old' age category (46 years or older) was 60.9 ( $S E=0.55, N=666)$. The parameter estimate for age is positive (linear effect in Regr. 1: $\beta_{3}=0.13$ and Regr. 2: $\beta_{3}=0.14$ ) and for age-squared is negative (quadratic effect in Regr. 2 : $\beta_{4}=-0.11$ ). ${ }^{13}$ The hypothesis is consequently supported by the evidence. The strongest driver of MEK was shown to be education $\left(\beta_{3}=0.341\right)$, followed by gender $\left(\beta_{1}=0.21\right)$.

\subsection{Exploring differences in MEK}

In order to test the possible differences in the level of MEK, as assumed in $\mathrm{H}_{4}$ to $\mathrm{H}_{10}$, we asked further questions to a randomly selected subsample of main study participants. For analysis of the differences we used $t$-tests, with the exception of television consumption where we used a linear regression. This subsample comprised 245 German citizens, of whom $49.8 \%$ were female and $50.2 \%$ were male. Mean age was 49.9 years $(S D=15.9, N=245)$. The average monthly household income, after taxes, was $1,976 €$

\footnotetext{
13 Age was centered before calculating the quadratic term to reduce problems associated with multicollinearity (tolerance $=0.962$, VIF $=1.040$ ) (Allison 1999).
}

( $S D=1,559 €, N=81$ ). In this subsample, $20.8 \%$ had a university degree $(N=243)$. The MEK values ranged from 12.5 to 95.8 points. The average was 62.3 $(S D=14.1, N=245)$. Consumers who were socialized in former East Germany $(M=59.4, S E=3.06$, $N=31$ ) reached an MEK of, on average, five points lower than consumers who were socialized in West Germany $[M=64.1, S E=0.96, N=162, t(36.07)=$ $1.46, \mathrm{p}=0.07]$. We therefore find tentative support for Hypothesis $\mathrm{H}_{4}$.

The average MEK of consumers who had a personal motive to engage with the economy was 64.7 $(S E=1.72, N=56)$ versus $61.5(S E=1.00, N=187)$ for consumers who did not have a major personal motive $\quad[t(241)=1.55, \quad p=0.04]$. Respondents listed the following reasons for dealing with the economy: investment/property management (35.3\%), profession (35.3\%), discussions (11.8\%), education (7.9\%), family (3.9\%), and others (5.8\%). Accordingly, Hypothesis $\mathrm{H}_{5}$ does not have to be rejected.

Consumers who took an economics course scored an MEK of 63.6 ( $S E=1.78, N=67)$ while consumers who did not take one scored an MEK of 61.7 $[S E=0.99, N=170, t(235)=0.97, p=0.34]$. On the basis of this result, Hypothesis $\mathrm{H}_{6}$ cannot be accepted.

Watching a significant amount of television decreased participants' MEK, as was proposed in Hypothesis $\mathrm{H}_{7}$ : For every hour per day a person consumed television, his or her MEK dropped by about 1.5 points ( $\beta=-1.62, p=0.03, \beta$ unstandardized).

Viewers of sensationalist news had an average MEK of $54.5(S E=2.66, N=29)$. In contrast, the average MEK of 'serious' news viewers was almost ten points higher, $M=63.7 \quad[S E=1.34, \quad N=103]$. Similarly, readers of the yellow press reached an average MEK score of 56.9 ( $S E=2.93, N=31$ ) and 'serious' newspaper readers had an average score of 67.0 $(S E=1.96, N=29)$. Hypotheses $\mathrm{H}_{8}$ and $\mathrm{H}_{9}$ can therefore be substantiated by the results.

The effect of economic knowledge on socio-political opinions differed according to the issues. We found an effect of MEK on agreement with 'Stuttgart 21' [proponents: $M=65.9, S E=1.87, N=38$; opponents: $M=59.6, S E=1.36, N=122$ ]. For agreement with extending the operating times of nuclear power plants, the mean MEK of the proponents was 64.4 ( $S E=2.07, N=45$ ) and that of the opponents was $58.1(S E=2.11, N=48)[t(91)=2.16, p=0.03]$. For agreement with Thilo Sarrazin's immigration theses, we found no effect of MEK [proponents $M=62.4$, $S E=1.48, N=90$; opponents $M=62.7, S E=1.48$, $N=71$. We therefore can only partially find support for Hypothesis $\mathrm{H}_{10}$. 


\section{General discussion, implications, limitations and conclusion}

Although research acknowledges the importance of consumers' economic knowledge, little is known about the extent and drivers of such knowledge outside the US. Our studies address this research gap by conceptualizing and testing minimal economic knowledge of consumers in Germany. Applying the Delphi method and pretesting, we were able to create a questionnaire for assessing minimal economic knowledge of consumers in Germany. To test the Status quo of MEK in Germany using the developed questionnaire, we conducted an empirical study with 1,314, respectively 245 participants. We found a severe knowledge deficiency of economic facts, concepts, and causal relationships in the population. Only a weak relationship could be found between one's self-assessment and the level of MEK, which is in line with previous studies (Walstad and Larsen 1992). Participants who ranked their economic knowledge as good had, in general, higher scores than those who rated it as poor. However, as less than half of the sample correctly assessed their economic knowledge, the question of how to improve selfevaluation of knowledge arises.

We found that three drivers (being male, having a higher educational level, being older) made a positive contribution to economic knowledge. We found a gender effect, revealing that women had less economic knowledge than men. However, the magnitude of the difference is nevertheless surprising, given that women participate in the economy today much more than in past decades. When results from time series are available in future research, it will be very useful to observe whether this knowledge gap diminishes. We find first evidence that this huge gap between men and women could be on a decline: Male participants aged 60 years and older had a mean of 65.5 ( $S E=0.98, N=188$ ), and females in this age group had a mean of 56.3 [ $S E=1.33$, $N=120]$. We therefore find a gender difference of ten points for participants older than 60 years. This substantial difference decreases to less than three points for the young: Male participants aged thirty years and younger had a mean of $57.3(S E=1.27$, $N=134$ ), and females in this age group had a mean of 52.9 [SE $=1.33, N=114]$.

As assumed, access to education is a critical aspect in strengthening levels of MEK. People with a college or university degree demonstrated levels of MEK ten points above the average score. As is observable from the regression analysis, and confirming indications from previous studies (Gleason and van Scyoc 1995; Walstad and Larsen 1992), education is undoubtedly the strongest driver of MEK. From the standpoint that the general lack of economic knowledge must be overcome in order to develop a sustainable society, the education system is an important platform for such an effort.

Another driver of MEK is age, which in our results follows an inverted U-shaped function, demonstrating that economic knowledge increases up to a certain age, and then begins to decrease. In line with prior research (Bucher-Koenen and Lusardi 2011), a decrease in knowledge can be observed after the age of 60 years, when people generally become more forgetful. Our results also closely align with the study of Christelis et al. (2010), which shows a positive relationship between cognitive abilities and economic decision making. Economic education should start at an early age, so that a lack of knowledge and understanding does not persist throughout a lifetime. It is therefore important to consider age when analyzing a person's economic decisions. Economic decision making for the elderly may, therefore, necessitate a different kind of counselling than would be appropriate for younger people.

In a complementary empirical study using a subsample we posed several additional questions concerning possible factors influencing the level of MEK. An area of inquiry related to their socialization-the settings in which participants lived or currently do live, and the places where they learned whatever they know of economics. People socialized in the former East German states had lower levels of MEK than people from the former West German states. The differences in both the educational programmes and in the economic environments of the divided East and West Germany could explain the differences in MEK. Moreover, the knowledge of the people socialized in the former East Germany may continue to be affected by inferior economic conditions-given that unemployment rates remain higher and wages are lower in that region than in the former West Germany (Lechner et al. 2007). Approaches to enhance minimal economic knowledge should therefore consider differences in socialisation.

Given that people with a current reason to inform themselves about the economy evidenced higher MEK scores, it is also important to demonstrate the personal motive of economic knowledge to the general public. The rationale behind this observation is that people will put more effort into accumulating 
information about the economy if they enjoy learning about it and if it has personal meaning for them. Therefore, efforts to develop strategies for raising public awareness of economic information should incorporate evidence that economic knowledge has important personal relevance. ${ }^{14}$

Our results concerning the value of economics courses for MEK proficiency indicate that the existing training formats in economics (such as school or education centre courses) do not function effectively, inasmuch as those students who took an economics course-and hence should have a better understanding of economic issues-did not achieve a higher MEK score. In view of this, the development of innovative and successful teaching formats for transferring economic knowledge deserves special attention.

The amount of television consumption presented itself as a factor affecting economic knowledge. Generally, the more television a person watched, the less economic knowledge she or he possessed. However, the more critical issue is the very strong effect on MEK scores that results from the source of information-the type of information that is conveyed. A difference of about ten points was observed between the higher MEK scores that resulted from 'serious' information sources and the lower levels resulting from the sensationalist sources (for both television and newspapers). Clearly, this outcome confirms the logical assessment of sensationalist information sources as less useful mechanisms for conveying quality economic information. However, almost all such sources are unambiguously formats that aim to entertain, not to provide economic knowledge, so are not to be faulted for the lower quality of that information. Nevertheless, one could argue that people with a low level of MEK do not watch or read 'serious' sources because they are intellectually less able to understand them, and that those serious formats are also not positioned to provide a better economic education for the wider audience. The key is to cue the audiences of the sensationalist sources to understand the level of information they are receiving. A strategic plan to advance MEK levels across the

\footnotetext{
$\overline{14}$ However, the direction of this effect remains unclear as this effect may be endogenous. For example, people who want to make an investment may have a high personal motive to acquire knowledge. On the other hand, they may also have a higher personal relevance as a result of their high economic knowledge. For example, they might have taken a mandatory economics course they did not choose to attend out of personal interest but may discover their interest in the economy in this course.
}

broader society would recognize the value of encouraging those persons who enjoy the sensationalist information sources to access other, more educational sources in order to develop a better understanding of economic issues.

This study shows that consumers do not receive MEK scores close to 100 and therefore are not economically literate. Accepts that improving the economic maturity of the consumers should be at the centre of establishing a responsible civil society, the following implications for consumer policy-making may be deducted from our results:

(1) Enabling of consumer self-determination

As the results demonstrate, a lack of minimal economic knowledge of the population is clearly prevalent and needs to be overcome. A mandatory 'Introduction to economics and consumerism' course in school may improve general understanding of business matters and also help individuals to make sound decisions, for example, in investments or taking out a loan. However, as our results show, the teaching formats and the transfer of knowledge need special attention, given that we did not find improved economic knowledge in people who took a traditional economics course. The demonstration of personal motive of the economy should be a focus of those formats as we found a strong influence of considering the economy personally relevant on economic knowledge. Educating and enabling consumers about the economy should start at an early age, for example, by providing children with an allowance that they manage themselves. Several promising approaches already exist, such as the initiative for consumer competence of the BMELV (German Federal Ministry of Food, Agriculture, and Consumer Protection), which begins its campaign to enhance consumer sovereignty beginning in schools (BMELV 2010).

(2) Improvement of communication

Ignorance of economic issues seen in many segments of the population may be due to an inability to understand the basic vocabulary and principles of the economy-matters consumer encounter in everyday events through news organizations, politicians, and even bank customer advisors (Blendon et al. 1997). Even when there is an understanding of the importance of economic matters, it is more likely that many persons do not engage with these issues simply because they do not understand the 
terminology. To overcome difficulties in comprehension, the economic news, the governmental or business policies, and financial decisions to make on an individual level must be communicated in a way that is receiver-oriented and accessible for all segments of the population.

(3) Considering overconfidence of consumers Consumers may not be aware of their knowledge deficiencies, as demonstrated by our results and the literature (Jappelli 2010). The problem is that consumers only know what they need to know when they actually must know it and they detect their deficits. It is therefore important to make consumers aware of their potential overconfidence and motivate them to overcome their knowledge deficits. Otherwise they may make wrongful economic decisions or may even be misled as they overestimate their knowledge and forgo counselling and gathering more information.

As is the nature of research, the present study has limitations. We realize that, as a first study in this context, the unintended effects of the survey design, the brevity of the survey, and the limited range of questions cannot be excluded from consideration when interpreting the results, and, as the number of questions that could have been asked in this context is unlimited, we are aware that another set of experts would probably have come to a different set of MEK questions. Therefore, we are treating the questions as selected-but not exclusive-proxies for measuring MEK. Even with recognition of those limitations, however, implications deduced from our results emphasize the need for new forms of economic education, improved communication of economic issues, and cultivation of economically mature citizens.

Only those who have minimal economic knowledge can act in an informed way, so the lack of economic understanding poses considerable concerns not only for Germany, but for all nations. There have been first studies in consumer research linking economic literacy to energy consumption, savings (Attaria et al. 2010) or to consumer behaviour (Adkins and Ozanne 2005; Viswanathan et al. 2005), but it is essential to link economic literacy to economic decision making as well. We hope that the results presented here will make a useful contribution to this important line of consumer research.
Acknowledgments We would like to thank an anonymous reviewer for very valuable feedback, Deborah C. Nester for proofreading and the experts of the Delphi study for enabling us to develop this MEK questionnaire and for supportive discussions on the topic.

\section{References}

Adkins NR, Ozanne JL (2005) Critical Consumer Education: Empowering the Low-Literate Consumer. J Macromark 25:153-162

Allison PD (1999) Multiple regression: a primer. Pine Forge Press, Thousand Oaks

Attaria SZ, DeKayb ML, Davidsonc CI, de Bruinc WB (2010) Public perceptions of energy consumption and savings. PNAS 107:16054-16059

Bachmann LM, Gutzwiller FS, Puhan MA, Steurer J, Steurer-Stey $C$ and Gigerenzer G (2007) Do citizens have minimum medical knowledge? A survey. BMC Med 5

Blavatskyy PR (2009) Betting on own knowledge: experimental test of overconfidence. J Risk Uncertain 38(1):39-49

Blendon R, Benson J, Brodie M, Morin R, Altma D, Gitterman D, Brossard M, James M (1997) Bridging the gap between the public's and economists' views of the economy. J Econ Perspect 11:105-188

Blinder AS, Krueger AB (2004) What does the public know about economic policy, and how does it know it? Brookings Papers Econ Act 2004:327-387

BMELV (2010) Wollen wirklich alle den "mündigen Verbraucher”? Wie Interessengruppen ein Leitbild instumentalisieren, Stellungnahme des Wissenschaftlichen Beirats Verbraucher- und Ernährung beim BMELV: Bundesministerium für Ernährung, Landwirtschaft und Verbraucherschutz

Bucher-Koenen T, Lusardi A (2011) Financial literacy and retirement planning in Germany. J Pension Econ Financ 10:565-584

Caplan B (2002) Systematically biased beliefs about economics: robust evidence of judgemental anomalies from the survey of Americans and economists on the economy. Econ J 112:433-458

Chen H, Volpe RP (1998) An analysis of personal financial literacy among college students. Financ Serv Rev 7:107-128

Christelis D, Jappelli T, Padula M (2010) Cognitive abilities and portfolio choice. Eur Econ Rev 54:18-38

Cook RD, Weisberg S (1983) Diagnostics for heteroscedasticity in regression. Biometrika 70(1):1-10

Danaher K, Crandall CS (2008) Stereotype threat in applied settings re-examined. J Appl Soc Psychol 38:1639-1655

Enste DH, Haferkamp A, Fetchenhauer D (2009) Unterschiede im Denken zwischen Ökonomen und Laien - Erklärungsansätze zur Verbesserung der wirtschaftspolitischen Beratung. Perspektiven der Wirtschaftspolitik 10:60-78

Evanschitzky H, Ahlert D, Blaich G, Kenning P (2007) Knowledge management in knowledge-intensive service networks. Manage Decis 45:265-283

Federal Republic of Germany (2005) Working together for Germany-With courage and compassion. Coalition Agreement between the CDU, CSU and SPD, pp 129-131

Federal Statistical Office of Germany (2010) Statistisches Jahrbuch 2010. Wiesbaden 
Genova BKL, Greenberg BS (1979) Interests in news and the knowledge gap. Public Opin Q 43:79-91

Gigerenzer G (2014) Risk savvy: how to make good decisions. Viking, NY

Gleason J, van Scyoc LJ (1995) A report on the economic literacy of adults. J Econ Educ 26:203-210

Gripsund J (1999) In television and common knowledge. Routledge, London

Hancox RJ, Milne BJ, Poulton R (2005) Association of television viewing during childhood with poor educational achievement. Arch Pediatr Adolesc Med 159:614-618

Hill KQ, Hinton-Anderson A (1995) Pathways of representation: a causal analysis of public opinion-policy linkages. Am J Polit Sci 39:924-935

Howard MM (2003) In the weakness of civil society in postcommunist Europe. Cambridge University Press, Cambridge

Jacoby J (1977) Information load and decision quality: some contested issues. J Mark Res 14:569-573

Jappelli T (2010) Economic literacy: an international comparison. Econ J 120:F429-F451

Kaplan HS, Hill K, Lancaster JB, Hurtado AW (2000) A theory of human life history evolution: diet, intelligence, and longevity. Evolut Anthropol 9:156-185

Kennedy JF (1962) Special message to the congress on protecting the consumer interest

Kenning P, Reisch L (2013) Alternativen zum Informationsparadigma der Verbraucherpolitik. J Consum Prot Food Saf 8(3):227-253

Kenning P, Wobker I (2012) Die negativen Folgen von Kundenverwirrtheit und die moderierende Rolle von Vertrauen in der Konsumgüterdistribution. Konzeptionelles Modell und empirische Befunde. In: Ahlert D, Kenning P, Olbrich R, Schröder H (eds) Vertikale Preisund Markenpflege im Kreuzfeuer des Kartellrechts. Springer, Gabler, Wiesbaden, pp 69-93

Kenning P, Wobker I (2013) Ist der “mündige Verbraucher” eine Fiktion? Ein kritischer Beitrag zum aktuellen Stand der Diskussion um das Verbraucherleitbild in den Wirtschaftswissenschaften und der Verbraucherpolitik. Zeitschrift für Wirtschafts- und Unternehmensethik 2:282-300

Kirkwood TBL (1990) The disposable soma theory of aging. In: Harrison DE (ed) Genetic effects on aging II. Telford, Caldwell, pp 9-19

Lechner M, Miquel R, Wunsch C (2007) The curse and blessing of training the unemployed in a changing economy: The case of East Germany after unification. German Econ Rev 8:468-509

Linstone HA, Turoff M (1975) In the Delphi-method-techniques $\&$ applications. Addison-Wesley, London

Lusardi A, Mitchell OS (2011) Financial literacy around the world: an overview. J Pension Econ Financ 10:497-508

Micklitz H-W, Oehler A, Piorkowsky M-B, Reisch LA and Strünck C (2010) The consumer-trusting, vulnerable or responsible? Plea for a differentiated strategy in consumer policy. Statement by the Scientific Advisory Board on Consumer and Food Policies at the Federal Ministry of Consumer Protection, Food and Agriculture (BMELV), Berlin

Nilsson L-G, Sternäng O, Rönnlund M, Nyberg L (2009) Challenging the notion of an early-onset of cognitive decline. Neurobiol Aging 30:521-524

Nonaka I (1994) A dynamic theory of organizational knowledge creation. Org Sci 5:14-37

O’Brien RM (2007) A caution regarding rules of thumb for variance inflation factors. Qual Quant 41(5):673-690

Oehler A (2011) Behavioral Economics und Verbraucherpolitik: Grundsätzliche Überlegungen und Praxisbeispiele aus dem Bereich Verbraucherfinanzen. BankArchiv 59:707727

Oehler A, Kenning P (2013) Evidenzbasierung ermöglichen! Auf dem Weg zu einer realitätsnahen und empirisch fundierten Verbraucherpolitik. Stellungnahme des wissenschaftlichen Beirats Verbraucher- und Ernährungspolitik beim BMELV, September 2013 (mit Anmerkungen von: Kornelia Hagen, Christa Liedtke, Ulf Schrader)

Oehler A, Reisch LA (2008) Behavioral Economics-Eine neue Grundlage für die Verbraucherpolitik. Berlin

Podsakoff PM, MacKenzie SB, Lee JY, Podsakoff NP (2003) Common method biases in behavioral research: a critical review of the literature and recommended remedies. J Appl Psychol 88:879-903

Pressley M, Borkwski JG, Schneider W (1989) Good information processing: what it is and how education can promote it. Int J Educ Res 13:857-867

Reisch LA (2004) Principles and Visions of a New Consumer Policy: Discussion Paper by the Scientific Advisory Board for Consumer, Food, and Nutrition Policy to the German Federal Ministry of Consumer Protection, Food, and Agriculture. J Consum Policy 27:1-42

Roos MWM (2007) Ökonomisches Laiendenken in der Wirtschaftswissenschaft. Wirtschaftspsychologie 4:25-34

Schmader T, Johns M, Forbes C (2008) An integrated process model of stereotype threat effects on performance. Psychol Rev 115:336

Steiner P (2001) The sociology of economic knowledge. Eur J Social Theory 4:443-458

United Nations (1985) United Nations Guidelines for Consumer Protection

van Witteloostuijn A (1990) Leaning in economic theory: a taxonomy with an application to expectations formation. J Econ Psychol 11:183-207

Viswanathan M, Rosa JA, Harris JE (2005) Decision making and coping of functionally illiterate consumers and some implications for marketing management. J Mark 69:15-31

Walstad W (1996) Economic knowledge and the formation of economic opinions and attitudes. In: Lunt P, Furham A (ed) Economic socialization. The economic beliefs and behaviours of young people. Edward Elgar, Aldershot, pp 162-182

Walstad W (1997) The effect of economic knowledge on public opinion of economic issues. J Econ Educ 28:195-205

Walstad W, Allgood S (1999) What do college seniors know about economics? Am Econ Rev 89:350-354

Walstad W, Larsen M (1992) A national survey of American economic literacy. Lincoln, NE

Walstad W, Soper JC (1989) What is high school economics? Factors contributing to student achievement and attitudes. J Econ Educ 20:23-38

Weck-Hannemann $\mathrm{H}$ (2000) Frauen in der Ökonomie und Frauenökonomik: Zur Erklärung geschlechtsspezifischer Unterschiede in der Wirtschaft und in den Wirtschaftswissenschaften. Perspektiven der Wirtschaftspolitik 1:199-220

Werner C, Oehler A (2009) Verbraucherbildung und Verbraucherberatung in der Altersvorsorge: ein Überblick über deutsche und britische Initiativen. Vierteljahrshefte zur Wirtschaftsforschung/Quarterly. J Econ Res 78(3):125-143

Williams ML, Waldauer C, Duggal VG (1992) Gender differences in economic knowledge: an extension of the analysis. J Econ Educ 23:219-231

Williamson MR, Wearing AJ (1996) Lay people’s cognitive models of the economy. J Econ Psychol 17:3-38 